\title{
Community Clinical Oncology Program
}

National Cancer Institute

\section{Source}

National Cancer Institute. Community Clinical Oncology Program. NCI Thesaurus. Code C16097.

The Community Clinical Oncology Program (CCOP) was established by the National Cancer Institute ( $\mathrm{NCl})$ in 1983. Through this program, community physicians work with scientists conducting $\mathrm{NCl}$-supported clinical trials. 